\title{
NOACs in Anesthesiology
}

\author{
Donat R. Spahn ${ }^{a}$ Jürg-Hans Beer ${ }^{b}$ Alain Borgeat ${ }^{c}$ Pierre-Guy Chassot ${ }^{d}$ \\ Christian Kern $^{\mathrm{e}}$ François Mach $^{f}$ Krassen Nedeltchev ${ }^{g}$ Wolfgang Korte ${ }^{\mathrm{h}}$ \\ ${ }^{\mathrm{a}}$ Institute of Anesthesiology, University and University Hospital Zurich, Zurich, Switzerland; ${ }^{\mathrm{b}}$ Department of Internal

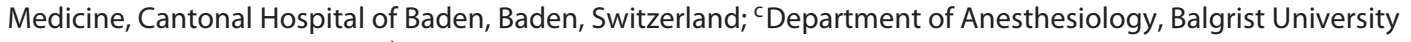 \\ Hospital, Zurich, Switzerland; ${ }^{d}$ Formerly Department of Anesthesiology, University Hospital of Lausanne (CHUV), \\ Lausanne, Switzerland; ' ${ }^{2}$ Department of Anesthesiology, University Hospital of Lausanne (CHUV), Lausanne, \\ Switzerland; ${ }^{f}$ Department of Internal Medicine, University Hospitals of Geneva (HUG), Geneva, Switzerland;

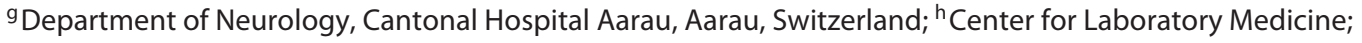 \\ Hemostasis and Hemophilia Center, St. Gallen, Switzerland
}

\section{Keywords}

New oral anticoagulants - Direct oral anticoagulants . Anesthesiology · Xa antagonist · Thrombin inhibitor

\begin{abstract}
Summary
Background: Due to increasing use of new oral anticoagulants (NOACs), clinicians are faced more and more frequently with clinical issues related to these drugs. Objective: The objective of this publication is to make practical suggestions for the perioperative management of NOACs as well as for their handling in overdoses and bleedings. Recommendations: In elective surgery and creatinine clearance $\geq 50 \mathrm{ml} /$ min, a NOAC should be discontinued $24-36 \mathrm{~h}$ before the intervention, and even earlier in case of reduced kidney function. In emergency interventions that cannot be delayed, the management is dependent on the NOAC plasma levels. With levels $\leq 30 \mathrm{ng} / \mathrm{ml}$, surgery can be performed. With levels $>30$ $\mathrm{ng} / \mathrm{ml}$, reversal agents should be considered. In low bleeding risk surgery, NOACs can be re-started $24 \mathrm{~h}$ after the intervention, which is prolonged to $48-72 \mathrm{~h}$ after surgery with high bleeding risk. In case of NOAC overdose and minor bleedings, temporary discontinuation and supportive care are usually sufficient to control the situation. In severe or lifethreatening bleedings, nonspecific and specific reversal agents should be considered.

(c) 2019 S. Karger AG, Basel
\end{abstract}

\section{KARGER}

(C) 2019 S. Karger AG, Basel

\section{Introduction}

New oral anticoagulant (NOAC) agents have been increasingly used in the prevention and treatment of thromboembolic events in the last few years. The four NOACs currently available in Europe directly target and inhibit either factor Xa (apixaban, edoxaban and rivaroxaban) or thrombin (dabigatran).

In addition to having numerous practical advantages - simple dosage schemes and no need for laboratory monitoring - over previous treatments using vitamin $\mathrm{K}$ antagonists (VKAs), NOACs are also demonstrating clinical benefits. Meta-analyses and systematic reviews comparing NOACs to the VKA warfarin provided evidence of NOACs having similar to superior efficacy in preventing stroke and systemic thromboembolic events in patients with non-valvular atrial fibrillation (nvAF), while significantly reducing the likelihood of major and especially intracranial bleeding [1-5].

While all four available NOACs are indicated and have proven efficacy in patients with nvAF as well as for treatment and secondary prophylaxis of deep-vein thrombosis and pulmonary embolism [6-12], only three (dabigatran, apixaban, rivaroxaban) have so far been cleared for the prevention of thromboembolic events after major knee or hip surgery in Europe and the US [13-18]. Only two (apixaban, rivaroxaban) are currently available for this indication in Switzerland [6, 7, 19] (table 1). 
Table 1. Approved indications and dosages of NOACs

\begin{tabular}{|c|c|c|c|c|}
\hline & $\begin{array}{l}\text { Dabigatran, } \\
\text { mg/day }\end{array}$ & $\begin{array}{l}\text { Apixaban, } \\
\text { mg/day }\end{array}$ & $\begin{array}{l}\text { Edoxaban, } \\
\text { mg/day }\end{array}$ & $\begin{array}{l}\text { Rivaroxaban, } \\
\text { mg/day }\end{array}$ \\
\hline \multicolumn{5}{|l|}{ Switzerland (swissmedicinfo.ch) } \\
\hline nvAF & $\begin{array}{l}2 \times 150 \\
2 \times 110^{1}\end{array}$ & $\begin{array}{l}2 \times 5 \\
2 \times 2.5^{3}\end{array}$ & $\begin{array}{l}1 \times 60 \\
1 \times 30^{6}\end{array}$ & $\begin{array}{l}1 \times 20 \\
1 \times 15^{7,8}\end{array}$ \\
\hline Therapy DVT/PE & $2 \times 150^{2}$ & $\begin{array}{l}2 \times 10 \text { for } 7 \text { days, } \\
\text { then } 2 \times 5\end{array}$ & $\begin{array}{l}1 \times 60^{2} \\
1 \times 30^{6}\end{array}$ & $\begin{array}{l}2 \times 15 \text { for } 3 \text { weeks, } \\
\text { then } 1 \times 20\end{array}$ \\
\hline Prevention of recurrent DVT/PE & $\begin{array}{l}2 \times 150 \\
2 \times 110^{1}\end{array}$ & $2 \times 2.5$ & $1 \times 60$ & $1 \times 20$ \\
\hline Prevention of TE in major hip or knee surgery & - & $2 \times 2.5^{4,5}$ & - & $1 \times 10^{9,10}$ \\
\hline \multicolumn{5}{|l|}{ Europe (EMA)16 } \\
\hline \multirow[t]{2}{*}{ nvAF } & $2 \times 150$ & $2 \times 5$ & $1 \times 60$ & $1 \times 20$ \\
\hline & $2 \times 110^{11}$ & $2 \times 2.5^{13}$ & $1 \times 30^{17}$ & $1 \times 15^{7,8}$ \\
\hline Therapy DVT/PE & $\begin{array}{l}2 \times 150 \\
2 \times 110^{11}\end{array}$ & $\begin{array}{l}2 \times 10 \text { for } 7 \text { days, } \\
\text { then } 2 \times 5\end{array}$ & $\begin{array}{l}1 \times 60 \\
1 \times 3017\end{array}$ & $\begin{array}{l}2 \times 15 \text { for } 3 \text { weeks, } \\
\text { then } 1 \times 20\end{array}$ \\
\hline Prevention of recurrent DVT/PE & $\begin{array}{l}2 \times 150 \\
2 \times 110^{11}\end{array}$ & $\begin{array}{l}2 \times 5 \\
2 \times 2.5^{14}\end{array}$ & $\begin{array}{l}1 \times 60 \\
1 \times 3017\end{array}$ & $\begin{array}{l}1 \times 20 \\
1 \times 10^{14,18}\end{array}$ \\
\hline Prevention of TE in major hip or knee surgery & $\begin{array}{l}1 \times 110 \mathrm{mg} \\
\text { first day, } \\
\text { then } 2 \times 110^{12}\end{array}$ & $2 \times 2.5^{15}$ & - & $1 \times 10^{10}$ \\
\hline $\begin{array}{l}\text { Prevention of atherothrombotic events after ACS with } \\
\text { elevated cardiac biomarkers }\end{array}$ & - & - & - & $2 \times 2.5^{9,19}$ \\
\hline $\begin{array}{l}\text { Prevention of atherothrombotic events in CAD or } \\
\text { symptomatic PAD }\end{array}$ & - & - & - & $2 \times 2.5^{9,20}$ \\
\hline
\end{tabular}

Table 1 continued on next page

Rivaroxaban, in combination with low-dose acetylsalicylic acid (ASA), is approved in Europe and the US for prevention of major cardiovascular events in patients with chronic coronary artery disease (CAD) or peripheral arterial disease (PAD) $[13,16]$.

Due to the widespread use of NOACs, clinicians are faced more and more frequently with issues concerning the perioperative management of such patients.

The aim of this publication is to provide a practical update about NOACs for the perioperative setting. It contains an overview of the pharmacological characteristics of the available NOACs and suggestions for procedures for the respective perioperative management of elective and emergency interventions. Other clinical situations, such as overdoses and bleeding under NOACs, will be addressed as well.

\section{Key Factors for the Preoperative Estimation of Bleeding Risk in NOAC Patients}

The intra- and postoperative bleeding risk is influenced by the product and application characteristics of the NOAC, patient-related factors, and the type of intervention. High bleeding risk means that a patient is at risk of losing a large amount of blood or bleeding occurs in a critical, closed space with potentially severe consequences.

NOACs in Anesthesiology

\section{NOACs: Approved Indications and Dosages}

All NOACs block an activated coagulation factor, either FXa (apixaban, edoxaban, rivaroxaban) or FIIa (thrombin; dabigatran), thus halting the coagulation cascade and preventing clot formation. Despite the similar mode of action, the different NOACs vary in several practically relevant aspects, such as their approved indications, pharmacokinetic properties, and dosage schemes. In table 1 the approved indications and corresponding dosage schemes recommended by Swiss, European and US American drug information agencies are listed. However, for some patients an adaptation of the dosage is advised, as age, body weight, and renal or liver functions can have an influence on the drug's dynamics $[6-9,20]$.

\section{Pharmacokinetic Profiles}

In order to perform surgery at a time of minimal bleeding risk, the timing of last intake and the pharmacokinetic properties of the NOAC used have to be considered, some of which are summarized in table 2. Especially the time to peak concentration $\left(\mathrm{T}_{\max } / \mathrm{C}_{\max }\right)$, the half-life $\left(\mathrm{T}_{1 / 2}\right)$ and the elimination pathway are important pieces of information that should be factored in patient management.

\section{Drug Interactions}

NOACs were developed to offer advantageous treatment alternatives to the VKAs $[24,25]$. The reduction of 
Table 1. Continued

\begin{tabular}{|c|c|c|c|c|}
\hline & $\begin{array}{l}\text { Dabigatran, } \\
\text { mg/day }\end{array}$ & $\begin{array}{l}\text { Apixaban, } \\
\mathrm{mg} / \text { day }\end{array}$ & $\begin{array}{l}\text { Edoxaban, } \\
\mathrm{mg} / \text { day }\end{array}$ & $\begin{array}{l}\text { Rivaroxaban, } \\
\text { mg/day }\end{array}$ \\
\hline \multicolumn{5}{|l|}{ USA (FDA) } \\
\hline \multirow[t]{2}{*}{ nvAF } & $2 \times 150^{21}$ & $2 \times 5$ & $1 \times 60^{27}$ & $1 \times 20^{29}$ \\
\hline & $2 \times 75^{22,23}$ & $2 \times 2.5^{25}$ & $1 \times 30^{28}$ & $1 \times 15^{30}$ \\
\hline Therapy DVT/PE & $2 \times 150^{21}$ & $\begin{array}{l}2 \times 10 \text { for } 7 \text { days, } \\
\text { then } 2 \times 5\end{array}$ & $\begin{array}{l}1 \times 60 \\
1 \times 30^{28}\end{array}$ & $\begin{array}{l}2 \times 15 \text { for } 3 \text { weeks, } \\
\text { then } 1 \times 20\end{array}$ \\
\hline Prevention of recurrent DVT/PE & $2 \times 150^{21}$ & $\begin{array}{l}2 \times 5 \\
2 \times 2.5^{14}\end{array}$ & no mention & $\begin{array}{l}1 \times 20 \\
1 \times 10^{14,18}\end{array}$ \\
\hline Prevention of TE in major hip or knee surgery & $\begin{array}{l}1 \times 110 \mathrm{mg} \text { first day, } \\
\text { then } 1 \times 220^{24}\end{array}$ & $2 \times 2.5^{26}$ & - & $1 \times 10^{26}$ \\
\hline $\begin{array}{l}\text { Risk reduction of major CV events (CV death, MI, } \\
\text { and stroke) in chronic CAD or PAD }\end{array}$ & - & - & - & $2 \times 2.5^{9,20}$ \\
\hline
\end{tabular}

nvAF = Non-valvular atrial fibrillation; DVT = deep-vein thrombosis; $\mathrm{PE}=$ pulmonary embolism; TE = thromboembolism; EMA = European Medicines Agency; ACS = acute coronary syndrome; CAD = coronary artery disease; $\mathrm{PAD}=$ peripheral arterial disease; FDA $=$ Food and Drug Administration; $\mathrm{CV}=$ cardiovascular.

${ }^{1} \mathrm{CrCl} 30-50 \mathrm{ml} / \mathrm{min}$, or $>80$ years.

${ }^{2}$ After initial treatment with UFH or LMWH for 5 days.

${ }^{3}$ Patients with at least two of the following criteria: age $\geq 80$ years, body weight $\leq 60 \mathrm{~kg}$, or serum creatinine $\geq 1.5 \mathrm{mg} / \mathrm{dl}(133 \mu \mathrm{mol} / \mathrm{l})$.

${ }^{4}$ Duration of treatment: hip replacement 32-38 days, knee replacement 10-14 days.

${ }^{5}$ Indication: elective hip and knee replacement.

${ }^{6} \mathrm{CrCl} 15-50 \mathrm{ml} / \mathrm{min}$, body weight $\leq 60 \mathrm{~kg}$, or concomitant therapy with potent P-gp inhibitors.

${ }^{7} \mathrm{CrCl} 30-49 \mathrm{ml} / \mathrm{min}$.

${ }^{8}$ Rivaroxaban is also admitted for $\mathrm{CrCl} 15-29 \mathrm{ml} / \mathrm{min}$; careful application required, no dosage recommendation.

${ }^{9} \mathrm{Can}$ be taken independent of food, whereas $15 \mathrm{mg}$ and $20 \mathrm{mg}$ should be taken with food to assure bioavailability.

${ }^{10}$ Duration of treatment: major hip surgery 5 weeks, major knee surgery 2 weeks.

${ }^{11}$ Age $\geq 80$ years, or patients receiving concomitant verapamil.

${ }^{12}$ Duration of treatment: hip replacement 28-35 days, knee replacement 10 days.

${ }^{13}$ Patients with at least two of the following criteria: age $\geq 80$ years, body weight $\leq 60 \mathrm{~kg}$, or serum creatinine $\geq 1.5 \mathrm{mg} / \mathrm{dl}(133 \mu \mathrm{mol} / \mathrm{l})$.

${ }^{14}$ After at least 6 months of treatment for DVT or PE.

${ }^{15}$ Duration of treatment: hip replacement 32-38 days, knee replacement 10-14 days.

${ }^{16} \mathrm{EMA}$ advises that 'edoxaban should only be used in patients with nvAF and high creatinine clearance after careful evaluation of the individual thromboembolic and bleeding risk'.

${ }^{17}$ Patients with one or more of the following clinical factors: $\mathrm{CrCl} 15-50 \mathrm{ml} / \mathrm{min}$, body weight $\leq 60 \mathrm{~kg}$, concomitant use of P-gp inhibitors.

${ }^{18}$ Patients with high risk of recurrent DVT/PE consider administering $1 \times 20 \mathrm{mg} / \mathrm{day}$.

${ }^{19}$ In combination with acetylsalicylic acid $(1 \times 75-100 \mathrm{mg} /$ day $)$ or acetylsalicylic acid $(1 \times 75-100 \mathrm{mg} /$ day $)$ in addition to either clopidogrel $(1 \times 75 \mathrm{mg} /$ day) or a standard dose of ticlopidine (once daily).

${ }^{20} \mathrm{In}$ combination with acetylsalicylic acid $(1 \times 75-100 \mathrm{mg} /$ day $)$.

${ }^{21} \mathrm{CrCl}>30 \mathrm{ml} / \mathrm{min}$.

${ }^{22} \mathrm{CrCl}$ between 15 and $30 \mathrm{ml} / \mathrm{min}$.

${ }^{23}$ If given with P-gp inhibitors dronedarone or systemic ketoconazole.

${ }^{24}$ Duration of treatment: hip replacement $28-35$ days.

${ }^{25}$ Patients with at least two of the following criteria: age $\geq 80$ years, body weight $\leq 60 \mathrm{~kg}$, or serum creatinine $\geq 1.5 \mathrm{mg} / \mathrm{dl}$.

${ }^{26}$ Duration of treatment: hip replacement 35 days, knee replacement 12 days.

${ }^{27} \mathrm{FDA}$ provides a boxed warning that "edoxaban should not be used in patients with $\mathrm{CrCl}>95 \mathrm{ml} / \mathrm{min}$.

${ }^{28}$ For patients with $\mathrm{CrCl} 15-50 \mathrm{ml} / \mathrm{min}$.

${ }^{29}$ If $\mathrm{CrCl}>50 \mathrm{ml} / \mathrm{min}$.

${ }^{30} \mathrm{If} \mathrm{CrCl} 15-50 \mathrm{ml} / \mathrm{min}$.

drug/drug and drug/food interactions are among the most relevant advantages of NOACs over VKAs [24, 26]. As NOACs are partially eliminated through P-glycoproteins (P-gp) transport proteins and cytochrome P450 enzymes, there is still a potential of interference with drugs that use the same pathways. Such interactions may ultimately lead to over- or under-anticoagulation [27].

Recommendations are mainly based on pharmacokinetic studies measuring plasma levels of drugs with the same metabolic pathways as NOACs, as only little data is available on the bleeding risk of combining NOACs with other medications. A new population-based cohort study with over 90,000 atrial fibrillation (AF) patients found a high risk of major bleeding for NOAC patients who were also taking amiodarone and fluconazole, in line with their respective pharmacokinetic data. Surprisingly, the higher risk of major bleeding was also prevalent for NOAC patients taking rifampicin and phenytoin, which, according to their pharmacokinetic profiles, lead to lower NOAC plasma levels - an unexplained fact caused by an un- 
Table 2. Pharmacokinetic characteristics of NOACs [6-9, 21]

\begin{tabular}{|c|c|c|c|c|}
\hline & Dabigatran & Apixaban & Edoxaban & Rivaroxaban \\
\hline Bioavailability & $6.5 \%$ & $52 \%^{1}$ & $62 \%$ & $\begin{array}{l}80-100 \%(10 \mathrm{mg}) \\
66-100 \%(20 \mathrm{mg})\end{array}$ \\
\hline Prodrug & yes & no & no & no \\
\hline $\mathrm{T}_{\max }$ & $0.5-2 \mathrm{~h}$ & $3-4 \mathrm{~h}$ & $1-2 \mathrm{~h}$ & $2-4 \mathrm{~h}$ \\
\hline $\mathrm{T}_{1 / 2}$ & $12-14 \mathrm{~h}$ & $\begin{array}{l}12 \mathrm{~h}(18-40 \mathrm{y}) \\
15 \mathrm{~h}(>65 \mathrm{y})\end{array}$ & $10-14 \mathrm{~h}$ & $\begin{array}{l}5-9 \mathrm{~h} \\
11-13 \mathrm{~h} \text { (elderly patients) }\end{array}$ \\
\hline $\begin{array}{l}\text { Trough median (P10-P90), or } \\
\text { anti-FXa minimum median [21] }\end{array}$ & $\begin{array}{l}2 \times 110 \mathrm{mg} / \mathrm{day}: \\
66(28-155) \mathrm{ng} / \mathrm{ml} \\
2 \times 150 \mathrm{mg} / \mathrm{day}: \\
93(40-215) \mathrm{ng} / \mathrm{ml}\end{array}$ & $\begin{array}{l}2 \times 2.5 \mathrm{mg} / \text { day: } \\
0.84(0.37-1.8) \mathrm{IU} / \mathrm{ml} \\
2 \times 5 \mathrm{mg} / \text { day: } \\
1.54(0.61-3.43) \mathrm{IU} / \mathrm{ml}\end{array}$ & $\begin{array}{l}1 \times 30 \mathrm{mg} / \text { day: } \\
0.35(0.21-0.57) \mathrm{IU} / \mathrm{ml} \\
1 \times 60 \mathrm{mg} / \text { day: } \\
0.64(0.37-1.12) \mathrm{IU} / \mathrm{ml}\end{array}$ & $\begin{array}{l}2 \times 15 \mathrm{mg} / \text { day: } \\
57(20-140) \mathrm{ng} / \mathrm{ml} \\
1 \times 20 \mathrm{mg} / \text { day: } \\
25.6(5.93-86.9) \mathrm{ng} / \mathrm{ml}\end{array}$ \\
\hline $\begin{array}{l}\text { Peak median (P10-P90), or } \\
\text { anti-FXa maximum median [21] }\end{array}$ & $\begin{array}{l}2 \times 110 \mathrm{mg} / \mathrm{day}: \\
133(52-275) \mathrm{ng} / \mathrm{ml} \\
2 \times 150 \mathrm{mg} / \mathrm{day}: \\
184(74-383) \mathrm{ng} / \mathrm{ml}\end{array}$ & $\begin{array}{l}2 \times 2.5 \mathrm{mg} / \text { day: } \\
1.3(0.67-2.4) \mathrm{IU} / \mathrm{ml} \\
2 \times 5 \mathrm{mg} / \mathrm{day}: \\
2.55(1.36-4.79) \mathrm{IU} / \mathrm{ml}\end{array}$ & $\begin{array}{l}1 \times 30 \mathrm{mg} / \text { day: } \\
2.1 \mathrm{IU} / \mathrm{ml} \\
1 \times 60 \mathrm{mg} / \text { day: } \\
3.8 \mathrm{IU} / \mathrm{ml}\end{array}$ & $\begin{array}{l}2 \times 15 \mathrm{mg} / \mathrm{day}: \\
229(180-320) \mathrm{ng} / \mathrm{ml} \\
1 \times 20 \mathrm{mg} / \mathrm{day}: \\
255(189-419) \mathrm{ng} / \mathrm{ml}\end{array}$ \\
\hline Elimination [22] & $\begin{array}{l}80 \% \text { renal } \\
20 \% \text { hepatic }\end{array}$ & $\begin{array}{l}27 \% \text { renal } \\
73 \% \text { hepatic }\end{array}$ & $\begin{array}{l}35 \% \text { renal } \\
65 \% \text { hepatic }\end{array}$ & $\begin{array}{l}33 \% \text { renal } \\
33 \% \text { hepatic } \\
33 \% \text { unchanged in urine }\end{array}$ \\
\hline Distribution volume & $60-701$ & 211 & 1071 & 501 \\
\hline Duration of action [23] & $24-36 \mathrm{~h}$ & $24 \mathrm{~h}$ & & $24 \mathrm{~h}$ \\
\hline Interaction [21] & substrate of $\mathrm{P}$-gp & $\begin{array}{l}\text { metabolized by } \\
\text { CYP3A4 and substrate } \\
\text { of P-gp }\end{array}$ & $\begin{array}{l}\text { substrate of P-gp, very } \\
\text { little metabolization by } \\
\text { CYP450 }\end{array}$ & $\begin{array}{l}\text { metabolized by CYP3A4, } \\
\text { CYP2J2 and substrate of } \\
\text { P-gp and BCRP }\end{array}$ \\
\hline Interference with food [21] & prolongs $\mathrm{C}_{\max }$ to $2 \mathrm{~h}$ & none & none & increases $\mathrm{AUC}^{2}$ to $39 \%$ \\
\hline \multicolumn{5}{|c|}{$\begin{array}{l}\mathrm{T}_{\max }=\text { Time to maximum plasma concentration; } \mathrm{T}_{1 / 2}=\text { half-life, time to } 50 \% \text { of maximum plasma concentration; } \mathrm{FXa}=\text { factor } \mathrm{X} \\
\mathrm{P} \text {-gp = P-glycoprotein; CYP3A } 4=\text { cytochrome P450 3A4; CYP450 = cytochrome P450; CYP2J2 = cytochrome P450 2J2; BRCP = breas } \\
\text { cancer resistance protein; } \mathrm{C}_{\max }=\text { maximum plasma concentration; AUC = area under the curve. } \\
{ }^{1} \text { No effect of meals. } \\
{ }^{2} \mathrm{AUC}=\text { Area under curve (plasma concentration-time curve). }\end{array}$} \\
\hline
\end{tabular}

known mechanism. Bleeding rates when taking other drugs that either inhibit CYP 3A4 or compete for P-gp, were not found to be increased [28]. Although this study with a Taiwanese population may not be generalized to Western patients, one should be mindful of amiodarone, especially in the perioperative setting, as it is a frequently used drug amongst NOAC users.

If co-administration of a NOAC with interacting agents cannot be avoided, then a monitoring could be beneficial before a surgical intervention [7, 22]. Details are summarized in table 3 .

\section{Disorders and Interventions with Increased Risk of Bleeding}

The bleeding risk of a patient undergoing surgery depends on the type of intervention, the patient's individual characteristics, and the co-medication used. Disorders known to increase a patient's susceptibility to bleeding are shown in table 4.

\section{Bleeding Risk of Surgical Interventions}

Usually emergency surgery is associated with high or increased bleeding risk. Many surgical interventions also increase the thromboembolic risk. So, both risks - the one for bleeding and the one for thromboembolic events must be balanced [30]. In table 5 bleeding and thromboembolic risks for common surgeries are listed.

\section{Coagulation Tests / Monitoring}

The NOACs' pharmacodynamic and pharmacokinetic profiles are well known, which makes their anticoagulation effects relatively predictable. Therefore, patients using NOACs do not require routine coagulation monitoring $[6,7,9,22,31]$.

However, in certain clinical circumstances specific coagulation tests are crucial, for example in situations of major bleeding, emergency surgery, stroke during treatment, or when the patient has developed renal failure [32].

NOAC-specific tests have to be used which measure the plasma drug level $(\mu \mathrm{g} / \mathrm{ml})$ or the anti-FXa activity (IU/ 
Table 3. Drug-drug interactions: effect on NOAC plasma-levels, adapted from [29]

\begin{tabular}{|c|c|c|c|c|c|}
\hline Drug & Mechanism & Dabigatran & Apixaban & Edoxaban & $\begin{array}{l}\text { Rivaroxa- } \\
\text { ban }\end{array}$ \\
\hline \multicolumn{6}{|l|}{ Antiarrhythmic drugs } \\
\hline Amiodarone & moderate P-gp competition & $\uparrow-\uparrow \uparrow$ & no data & $\uparrow \uparrow$ & $(\uparrow)$ \\
\hline Digoxin & P-gp competition & no effect & no effect & no effect & no effect \\
\hline Diltiazem & $\begin{array}{l}\text { P-gp competition and weak CYP3A4 } \\
\text { inhibition }\end{array}$ & no effect & & no data & $(\uparrow)$ \\
\hline Dronedarone & P-gp competition and CYP3A4inhibition & $\uparrow \uparrow \uparrow-\uparrow \uparrow \uparrow \uparrow$ & no data & $\uparrow \uparrow \uparrow$ & no data \\
\hline Quinidine & P-gp competition & $\uparrow \uparrow$ & no data & $\uparrow \uparrow \uparrow$ & no data \\
\hline Verapamil & $\begin{array}{l}\text { P-gp competition (and weak CYP3A4 } \\
\text { inhibition) }\end{array}$ & $\uparrow-\uparrow \uparrow \uparrow \uparrow$ & no data & $\uparrow \uparrow$ & $(\uparrow)$ \\
\hline
\end{tabular}

Other cardiovascular drugs

Atorvastatin

Antibiotics

Clarithromycin;

erythromycin

P-gp competition and CYP3A4 inhibition $\uparrow$

no data no effect

no effect

Rifampicin

moderate P-gp competition and CYP3A4 $\uparrow$ inhibition

P-gp/ BCRP and CYP3A4/CYP2J2 inducers $\downarrow \downarrow$

$\begin{array}{lll}\text { no data } & \uparrow \uparrow \uparrow & \uparrow-\uparrow \uparrow \\ \downarrow \downarrow & \downarrow \downarrow & \text { compensatory } \\ & \text { increase of active } & \\ & \text { metabolites }\end{array}$

Antiviral drugs

HIV protease inhibitors

(e.g. ritonavir)

P-gp and BCRP competition or inducer; no data

$\uparrow \uparrow \uparrow \uparrow \quad$ no data

$\uparrow \uparrow \uparrow \uparrow$

inhibition

Fungostatics

Fluconazole

moderate CPY3A4 inhibition

Itraconazole; ketoconazole; potent $\mathrm{P}$-gp and BCRP competition;

posaconazole; voriconazole CYP3A4

inhibition

\begin{tabular}{|c|c|c|}
\hline 10 data & no data & no data \\
\hline$\uparrow \uparrow \uparrow \uparrow$ & $\uparrow \uparrow \uparrow \uparrow$ & $\uparrow \uparrow \uparrow-\uparrow \uparrow \uparrow \uparrow$ \\
\hline
\end{tabular}

Immunosuppressives

Cyclosporin; tacrolimus

P-gp competition

not

no data

$\uparrow \uparrow \uparrow$

no data

Antiphlogistics

Naproxen

P-gp competition

no data

$\uparrow \uparrow$

no effect

no data

Antacids

H2B; PPI; Al-Mg-hydroxidegastrointestinal absorption

$\downarrow$

no effect no effect

no effect

Others

Carbamazepine,

phenobarbital, phenytoin

P-gp/BCRP and CYP3A4/CYP2J2 inducers $\downarrow \downarrow \downarrow$

$\downarrow \downarrow$

$\downarrow \downarrow$

$\downarrow \downarrow$

P-gp = P-glycoprotein; CYP3A4 =cytochrome P450 3A4; BRCP = breast cancer resistance protein; CYP2J2 = cytochrome P450 2J2; GI

$\uparrow$ up to $30 \%, \uparrow \uparrow$ up to $60 \%, \uparrow \uparrow \uparrow$ up to $90 \%, \uparrow \uparrow \uparrow \uparrow>90 \%$.

Table 4. Anamnestic risk factors and current disorders with increased bleeding risk

- Coagulation disorders

- Platelet disorders

- Active gastrointestinal ulcers

- Recent major bleeding (particularly intracranial)

- Recent biopsy, surgery or major trauma

- Bacterial endocarditis

- Liver disease (Child Pugh A, B)

- Severe renal failure $\mathrm{ml}$ ). It is important to note, however, that prospective endpoint-driven studies assessing the effect of monitoring ( \pm dosing adaptations based on these measurements) are lacking; as such, these measurements need to be performed and interpreted by specialists and should not be performed on a routine basis even in difficult/high-risk patients.

Also, in NOAC patients it may be indicated to carry out routine coagulation tests to assess the general coagulation status, especially when bleeding occurred or preoperatively. 
Table 5. Bleeding risk of elective surgeries, adapted from [30]

\begin{tabular}{|c|c|c|c|}
\hline & High risk & Medium risk & Low risk \\
\hline Bleeding complications & $\begin{array}{l}\text { intracranial surgery } \\
\text { spinal canal surgery } \\
\text { orbital surgery / posterior } \\
\text { chamber } \\
\text { major tumor surgery } \\
\text { heart surgery } \\
\text { thyroid gland surgery } \\
\text { liver and pancreas } \\
\text { resection }\end{array}$ & $\begin{array}{l}\text { remaining surgeries } \\
\text { colonoscopy, especially for biopsy and } \\
\text { polypectomy } \\
\text { ERCP with papillotomy } \\
\text { biopsies of parenchymatous organs } \\
\text { bronchoscopy with biopsies } \\
\text { serial teeth extractions, operative } \\
\text { tooth extraction, oral surgery }\end{array}$ & $\begin{array}{l}\text { transurethral surgery } \\
\text { lesophago-gastro-duodenoscopy, } \\
\text { endosonography } \\
\text { skin biopsies } \\
\text { dental hygiene, periodontal surgery, } \\
\text { dental treatments (except serial teeth } \\
\text { extractions) }\end{array}$ \\
\hline $\begin{array}{l}\text { Thromboembolic } \\
\text { complications }\end{array}$ & $\begin{array}{l}\text { endoprosthesis } \\
\text { proximal hip fractures } \\
\text { and plurifragmentary } \\
\text { fractures } \\
\text { major pelvic surgery } \\
\text { tumor surgery }\end{array}$ & $\begin{array}{l}\text { surgery on upper extremities and all } \\
\text { remaining interventions on lower } \\
\text { extremities } \\
\text { major visceral, urological and } \\
\text { gynecological surgeries ( }>30 \mathrm{~min}) \\
\text { lung, chest wall and mediastinum } \\
\text { surgeries } \\
\text { varicose vein surgery } \\
\text { vascular surgery }\end{array}$ & $\begin{array}{l}\text { minor visceral, urological and } \\
\text { gynecological surgeries }(<30 \mathrm{~min}) \\
\text { with no bed rest } \\
\text { orthopedic removal of metal with no } \\
\text { bed rest and no impairment of joint } \\
\text { mobility }\end{array}$ \\
\hline
\end{tabular}

Table 6. Interpretation of coagulation tests under NOAC, adapted from [34]

\begin{tabular}{lllll}
\hline \multirow{2}{*}{ Test } & Effect of & & & \\
\cline { 2 - 5 } & dabigatran & apixaban & edoxaban & rivaroxaban \\
\hline PT/INR & - & $(\uparrow)$ & $(\uparrow)^{1}$ & $\uparrow$ \\
aPTT & $\uparrow \uparrow$ & $(\uparrow)$ & $(\uparrow)^{1}$ & $(\uparrow)$ \\
TT & $\uparrow \uparrow \uparrow$ & - & - & - \\
Anti-FXa & - & $\uparrow \uparrow$ & $\uparrow \uparrow$ & $\uparrow \uparrow$ \\
\hline
\end{tabular}

$\mathrm{PT}=$ Prothrombin time; INR = internationalized normalized ratio; aPTT $=$ activated prothrombin time; $\mathrm{TT}=$ thrombin time; $\mathrm{FXA}=$ factor $\mathrm{Xa}$.

$\uparrow$ Prolonged coagulation test or elevated anti-FXa plasma levels.

${ }^{1}$ Prolonged, but no known relation with bleeding risk [29].

Table 6 may help with the interpretation of the test results, for which it is important to consider the time of last intake of the NOAC and the renal function [33].

Prothrombin time (PT): Even though PT is not the most effective test available, it is still widely used in practice for screening [35]. PT is generally not a recommended test for the direct FXa inhibitors as there is a high variability and normal values do not exclude clinically relevant levels of the drugs $[7,8,36,37]$. PT seems to be more sensitive towards rivaroxaban than to other FXa inhibitors $[6,33,38]$. PT is not sensitive to dabigatran, thus not recommended for its quantification [9].

Activated partial thromboplastin time (aPTT): Due to widespread use, around the clock availability, low cost and relatively good sensitivity, aPTT may be used for the monitoring of dabigatran and as a screening test for the risk of bleeding [39]. Again, this test is not useful and not recommended for rivaroxaban, apixaban and edoxaban, as values show a high variability $[6-8,33,36]$.

The aPTT could be useful for an urgent assessment of the presence of dabigatran, although normal values might still indicate a presence of the drug $[33,40]$.

Thrombin time (TT): This test is mainly useful to screen for the presence or absence of dabigatran, it is not useful for the direct FXa inhibitors [6-8, 34, 35]. A normal TT excludes the presence of dabigatran [41].

Anti-FXa: For rivaroxaban, apixaban and edoxaban the most accurate measurement of plasma concentration is done with the anti-FXa assay using the specific drug as calibrator $[6-8,33,34,37]$. In some clinics these tests are available $24 / 7$ with results obtained in about $20 \mathrm{~min}$, thus being a valid method even in urgent situations [22].

\section{Perioperative Management of NOACs}

\section{Elective Interventions}

The objective of the peri-interventional management of patients already under NOAC before surgery is to minimize the peri-interventional risk for thromboembolism and bleeding.

Except for surgical interventions with very low risk of bleeding, NOAC therapy needs to be interrupted $[42,43]$. Bridging is not recommended, as it has not been found to 
Table 7. Time of last drug intake, adapted from $[29,51]$

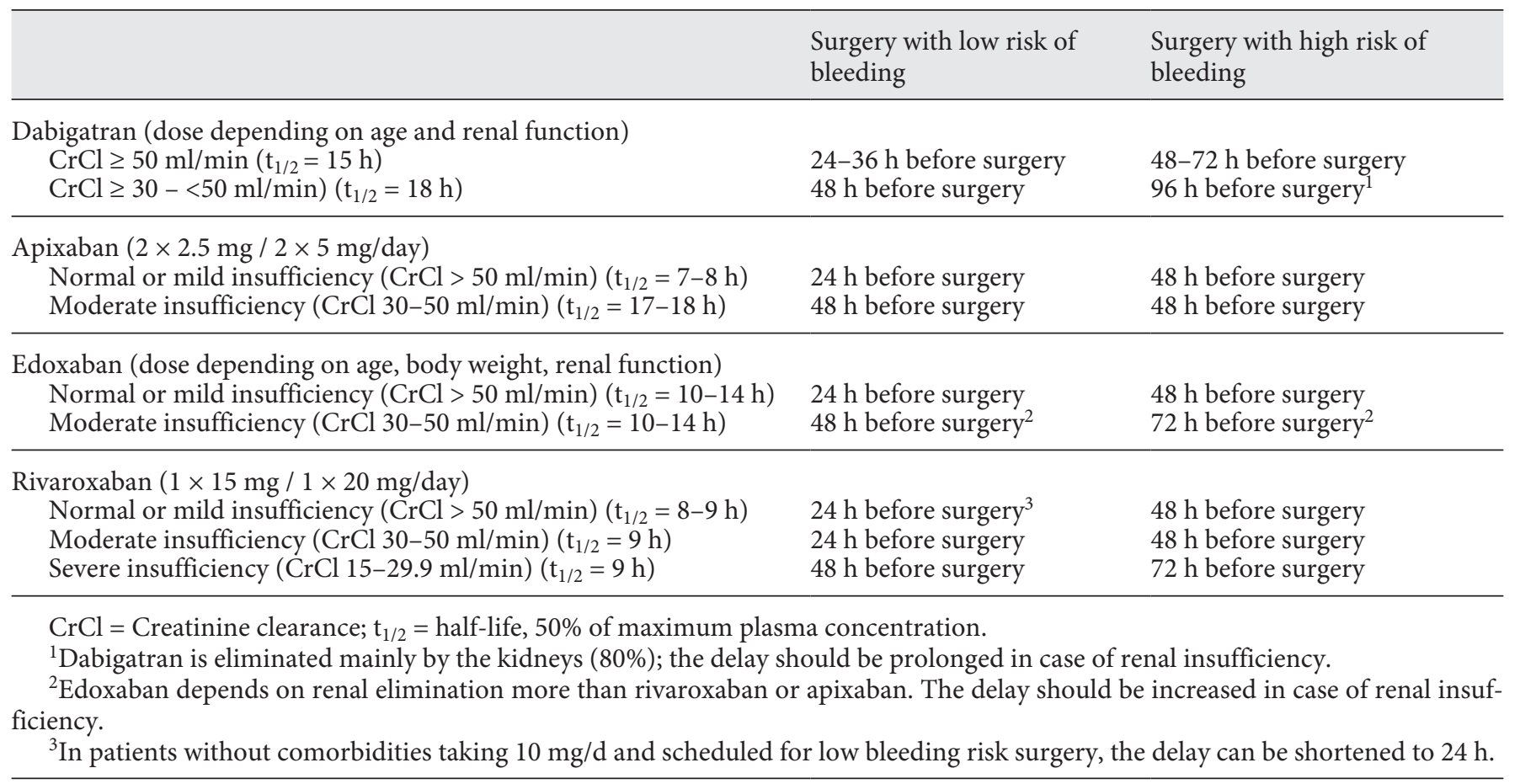

Table 8. Timing of NOAC re-start after surgery [51]

\begin{tabular}{|c|c|c|}
\hline Drug & Low bleeding risk surgery & High bleeding risk surgery \\
\hline Dabigatran & resume $24 \mathrm{~h}$ after surgery, $2 \times 150 \mathrm{mg} / \mathrm{day}^{1}$ & resume $48-72 \mathrm{~h}$ after surgery, $2 \times 150 \mathrm{mg} /$ day $^{1,2,6}$ \\
\hline Rivaroxaban & resume $24 \mathrm{~h}$ after surgery, $1 \times 20 \mathrm{mg} /$ day $^{1}$ & resume $48-72 \mathrm{~h}$ after surgery, $1 \times 20 \mathrm{mg} /$ day $^{1,3,6}$ \\
\hline Apixaban & resume $24 \mathrm{~h}$ after surgery, $2 \times 2.5 \mathrm{mg} /$ day $^{1}$ & resume $48-72 \mathrm{~h}$ after surgery, $2 \times 2.5 \mathrm{mg} /$ day ${ }^{1,4,6}$ \\
\hline Edoxaban & resume $24 \mathrm{~h}$ after surgery, $1 \times 60 \mathrm{mg} /$ day $^{1}$ & resume $48-72 \mathrm{~h}$ after surgery, $1 \times 30 \mathrm{mg} /$ day $1,5,6$ \\
\hline
\end{tabular}

${ }^{1}$ Or the pre-operative, indicated dosage [51].

${ }^{2}$ For patients at high risk for thromboembolism, consider administration of a reduced dose of dabigatran (e.g. $\left.1 \times 110-150 \mathrm{mg} / \mathrm{day}\right)$ on the evening after surgery and on the following day (first postoperative day) after surgery [59].

${ }^{3}$ For patients at high risk for thromboembolism, consider administration of a reduced dose of rivaroxaban $(\mathrm{e} . \mathrm{g} .1 \times 10 \mathrm{mg} / \mathrm{day}) \mathrm{on}$ the evening after surgery and on the following day (first postoperative day) after surgery [59].

${ }^{4}$ For patients at high risk for thromboembolism, consider administration of a reduced dose of apixaban (e.g. $\left.2 \times 2.5 \mathrm{mg} / \mathrm{day}\right) \mathrm{on}$ the evening after surgery and on the following day (first postoperative day) after surgery [51].

${ }^{5}$ For patients at high risk for thromboembolism, consider administration of a reduced dose of edoxaban (e.g. $\left.1 \times 30 \mathrm{mg} / \mathrm{day}\right) \mathrm{on}$ the evening after surgery and on the following day (first postoperative day) after surgery [51].

${ }^{6} \mathrm{LMWH}$ such as enoxaparin $1 \times 40$ or $2 \times 30 \mathrm{mg} /$ day or mechanical prophylaxis such as intermittent pneumatic compression can be considered until therapeutic anticoagulation can be re-introduced [59].

reduce thromboembolic events, but does increase the bleeding risk $[42,44-46]$. In cases where interruption is not necessary, procedures should be undertaken at trough and not at peak levels of NOAC.

Recommendations about pre-interventional discontinuation of NOACs vary. While for interventions with low bleeding risk an interruption of NOACs of $\geq 24 \mathrm{~h}$ is often considered as sufficient, the proposed period of time for interventions with high bleeding risk is between 2 and 5 days, for dabigatran up to 7 days [20,29, 47, 48]. These recommendations are not supported by clinical outcome data, but they rely on pharmacokinetic calcula- tions using elimination half-lives to predict NOAC levels with minimal bleeding risk.

It is usually assumed that an interruption of two to three half-lives of the drug is safe for low and intermediate hemorrhagic risk, and of four to five half-lives for high bleeding risk and neuraxial anesthesia. Renal insufficiency therefore may prolong these periods, depending on the specific NOAC and its renal elimination.

The recently published CORDIA study examined the necessary discontinuation period to reach NOAC levels of $\leq 30 \mathrm{ng} / \mathrm{ml}$, which were assumed to carry minimal bleeding risk [43]. Only $5 \%$ had NOAC levels of $>30 \mathrm{ng} / \mathrm{ml}$ 
Fig. 1. Emergency intervention schema, adapted after [54].

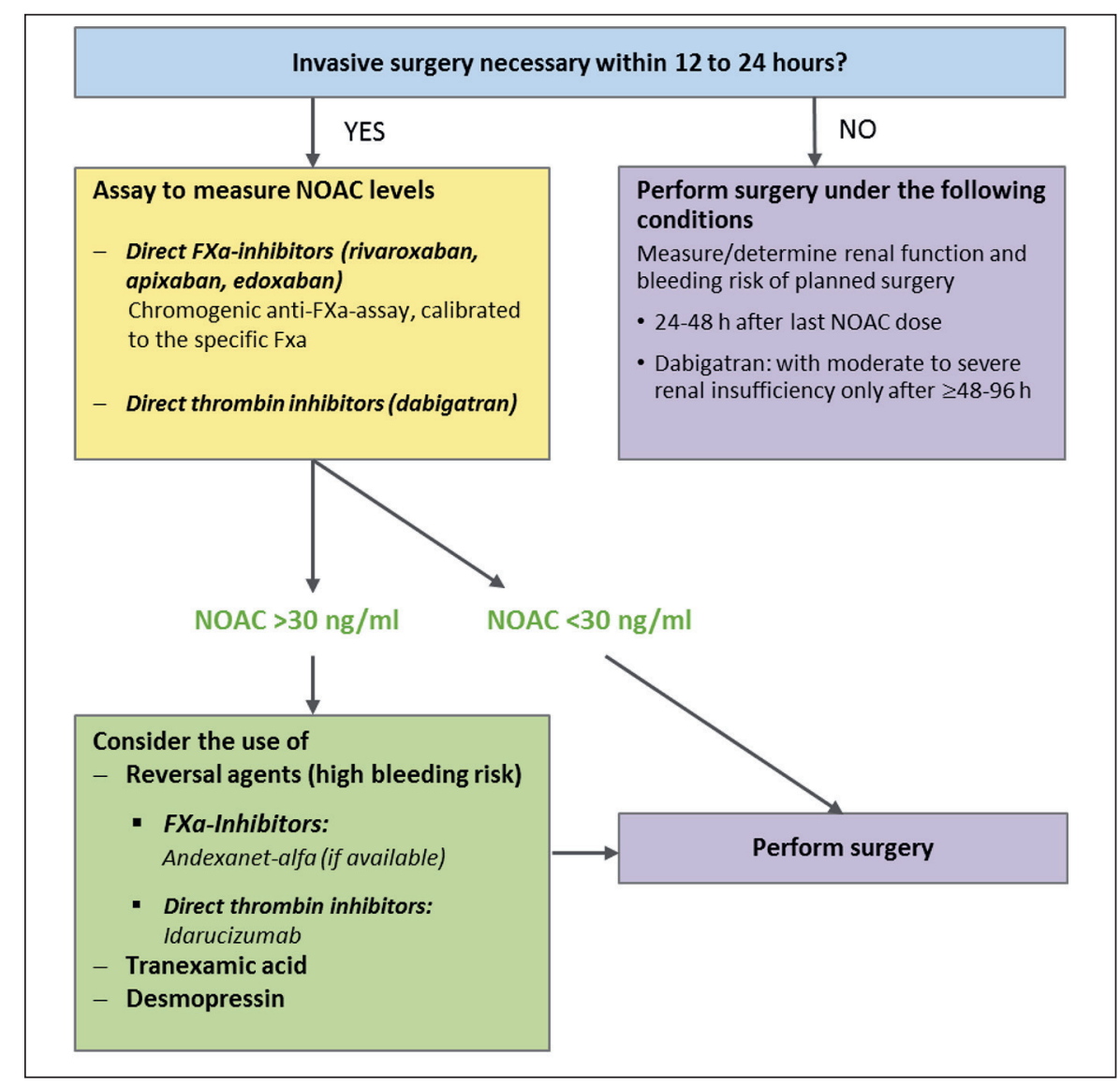

after $49-2 \mathrm{~h}$, and none $>50 \mathrm{ng} / \mathrm{ml}$. These figures were observed in patients with normal and reduced renal function, making it difficult to derive differentiated recommendations. For shorter discontinuation periods, there was a significant interindividual variability of plasma levels [43]. Another publication reported plasma levels of rivaroxaban that were higher than expected in patients with impaired kidney function (glomerular filtration rate $<60 \mathrm{ml} / \mathrm{min}$ ) and with co-medication amiodarone [49]. In unclear situations, it remains reasonable to measure NOAC plasma levels.

Based on the limited available data, the NOAC-free interval before intervention/surgery for patients with low bleeding risk and normal renal function should be $\geq 24 \mathrm{~h}$ (for details see table 7). Provided there is no clinical evidence of disturbed hemostasis, the NOAC can be re-started the day after the intervention (table 8). In patients with high bleeding risk and normal renal function the NOACfree interval before intervention/surgery is usually $\geq 48 \mathrm{~h}$ (for details see table 7), and re-start of the NOAC may take place on day 2 or 3 after the intervention, provided there are no signs of disturbed hemostasis or surgical contraindications [31] (table 8).

The PAUSE trial is expected to provide more data on the timing of last intake, plasma levels, and clinical outcome of NOACs [50].

\section{Emergency Interventions}

In emergency situations it is important to know the type of NOAC involved, the time of last intake, and the patient's renal function. If NOAC elimination is normal, the duration of action is $24 \mathrm{~h}$ for FXa antagonists and 24-36 h for dabigatran [23] (tables 2 and 7). Therefore, whenever possible, an intervention/surgery should be delayed by $24-48 \mathrm{~h}$ after last NOAC intake, in case of renal insufficiency even more (table 7) [51]. It may be helpful to know the NOAC plasma level, especially when the time of last intake is unknown or a relevant plasma level might still be present. The latter may be expected particularly in patients of advanced age ( $>75 / 80$ years), low body weight $(<60 \mathrm{~kg})$, and/or compromised renal function (creatinine clearance $<50 \mathrm{ml} / \mathrm{min}$ ). If it is unclear whether the test result represents a value from the ascending or descending slope of the NOAC plasma level curve, a second test after 3-4 h may bring clarification [31].

If an operation cannot be delayed, the further approach is based on the NOAC plasma level, provided there are no other obstacles. For the interpretation of the plasma level values, the time of last NOAC intake and renal function are important. Only little data is available on the relation between NOAC plasma levels and the bleeding risk in surgical interventions. Levels $<30 \mathrm{ng} / \mathrm{ml}$ are considered safe for high bleeding risk interventions, 
Table 9. Measures to influence the absorption and elimination of NOACs

\begin{tabular}{|c|c|c|c|c|}
\hline & Dabigatran & Apixaban & Edoxaban & Rivaroxaban \\
\hline Reduce absorption & - & \multicolumn{2}{|c|}{$\begin{array}{l}\text { activated charcoal until 2-4 } \\
\text { h (up to } 6 \text { h [60]) }\end{array}$} & $\begin{array}{l}\text { activated charcoal until } \\
8 \mathrm{~h}\end{array}$ \\
\hline Increase renal elimination & secure effective diuresis & sorbitol & secure effec & secure effective diuresis \\
\hline Hemodialysis & \multicolumn{2}{|c|}{ possible, limited experience ${ }^{1}$ not effective } & not effectiv & not effective \\
\hline
\end{tabular}

${ }^{1}$ Also risk of bleeding at puncture site [29].

whereas levels $>200 \mathrm{ng} / \mathrm{ml}$ are associated with a significant bleeding risk $[52,53]$.

With plasma levels between 30 and $200 \mathrm{ng} / \mathrm{ml}$, each case needs to be assessed individually, depending on the bleeding risk [29, 52] (fig. 1).

\section{Spinal and Epidural Anesthesia in Patients Treated with NOACs}

Guidelines that tackle NOAC management in neuraxial anesthesia make different recommendations about when to stop and when to resume these drugs before and after an intervention. The French Group on Perioperative Hemostasis (GIHP) for example recommends not to perform regional anesthesia techniques as long as a NOAC concentration is still prevalent [55]. Other recommendations suggest different timing schemes of cessation and re-initiation of anticoagulant treatment [56-58], or, depending on the type of anesthesia, if discontinuation is even necessary at all [56].

No definite evidence is available on this topic. The authors of this paper made a consensus-based conclusion: Both neuraxial puncture and the removal of a catheter have a comparable bleeding risk. The NOAC-free interval before these procedures corresponds with the surgical interventions with high bleeding risk, i.e. at least 5 half-lives (table 7).

Deep nerve blocks like psoas compartment or infraclavicular blocks are considered to carry the same bleeding risk as spinal and epidural anesthesia.

\section{Re-Start of NOACs after Intervention}

Same as before when undergoing surgery, the management of anticoagulation after an intervention needs to balance the bleeding risk of the intervention and the thromboembolic risk of the patient. The drug-specific guidelines indicate re-initiation of anticoagulation as soon as sufficient hemostasis has been accomplished (table 8) [6-9].

In patients at high risk of thromboembolism, postoperative bridging with low-molecular-weight heparin or intravenous unfractionated heparin (according to insti- tution protocol) can be considered until therapeutic anticoagulation can be re-introduced [59]; a reduced dose (e.g. rivaroxaban $1 \times 10 \mathrm{mg} /$ day) or mechanical prophylaxis such as intermittent pneumatic compression can also be considered [59].

\section{Overdoses, Intoxications and Bleeding}

\section{Management of Overdoses and Intoxications}

Overdoses of NOACs may occur in worsening of renal or hepatic function, incidentally or with suicidal intentions. If the elimination of the drug is not significantly reduced, the relatively short half-life of NOACs is an advantage compared to VKAs. In an unclear situation it may be helpful to determine plasma levels. Countermeasures may be considered, depending on the situation (table 9).

\section{Management of Active Bleeding}

When bleeding occurs, it is important to first assess the event according to severity of blood loss and location. Once more, it would be important to know the time of last intake and type of NOAC used as well as other factors that might influence plasma concentration and hemostasis [29]. In most non-life-threatening bleeding events, the temporary discontinuation of the NOAC and supportive care are sufficient to control the problem [61]. In a study with patients using rivaroxaban, even the majority of major bleedings (as defined by the International Society on Thrombosis and Hemostasis) could be managed with local therapy or red blood cell transfusions, with only $37 \%$ requiring an intervention or surgery [62].

If the clinical situation calls for a more urgent procedure, specific or non-specific reversal agents can be considered [63].

Currently, only dabigatran can be counteracted with a direct (or specific) reversal agent, idarucizumab (approved 2015 in the US and Europe and 2016 in Switzerland). It is highly important to repeat all coagulation tests 10 min after the administration of idarucizumab, because 
Table 10. Management of active bleeding, adapted after [31, 65]

\begin{tabular}{|c|c|c|}
\hline & \multicolumn{2}{|l|}{ General parameters } \\
\hline \multirow[t]{2}{*}{ Diagnostic } & \multicolumn{2}{|c|}{$\begin{array}{l}\text { Patient history } \\
\bullet \quad \text { Time of last NOAC intake } \\
\text { - Medication interactions } \\
\text { Potential accumulation (e.g. renal insufficiency) } \\
\text { Blood count, PT/INR, aPTT, thrombin time, fibrinogen } \\
\text { Renal function }\end{array}$} \\
\hline & Minor bleeding & Severe bleeding \\
\hline $\begin{array}{c}\text { Therapeutic } \\
\text { FXa }\end{array}$ & $\begin{array}{l}\text { - Symptomatic measures } \\
\text { - } \text { Intechanical compression } \\
\text { - Tranexamic acid i.v. } 10-15 \mathrm{mg} / \mathrm{kg} \text {, then } \\
1-5 \mathrm{mg} / \mathrm{kg} / \mathrm{h} \text {. } \\
\text { - Skip the next dosage. An interruption of } \\
\text { the anticoagulation is usually not } \\
\text { necessary }\end{array}$ & 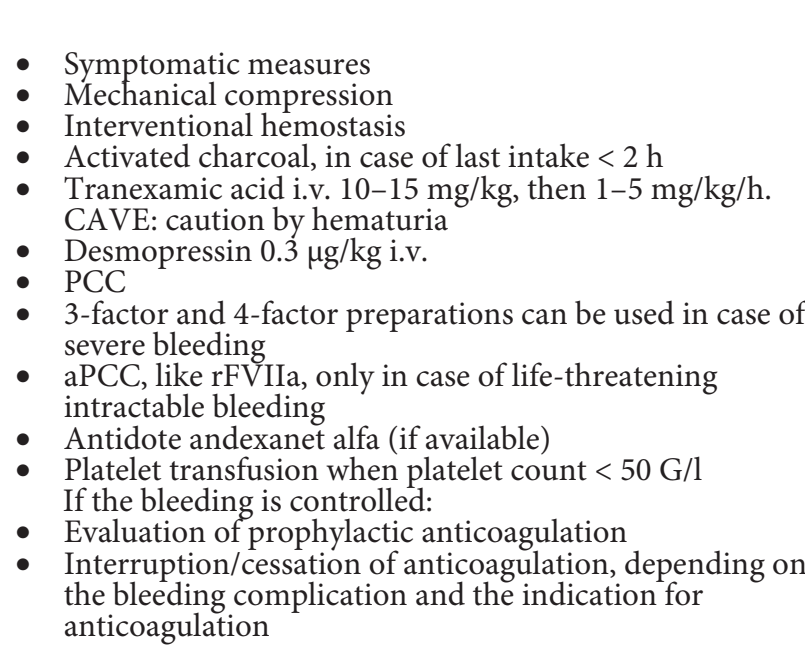 \\
\hline Dabigatran & $\begin{array}{l}\text { - Mechanical compression } \\
\text { - Trterventional hemostasis } \\
\text { - Skip the next dosage. An interruption of } \\
\text { the anticoagulation is usually not } \\
\text { necessary }\end{array}$ & $\begin{array}{l}\text { Mechanical compression } \\
\text { - Interventional hemostasis } \\
\text { - } \quad \text { Tranexamic acid } 1 \mathrm{~g} \text { i.v. } \\
\text { - One-time administration of idarucizumab } 5 \mathrm{~g} \\
\quad-\quad 2 \times 2.5 \mathrm{~g} / 50 \mathrm{ml} \text { over } 5-10 \text { min each, or } \\
\quad-\quad 2 \times \text { bolus injection consecutively } \\
\text { - Platelet transfusion, when platelet count }<50 \mathrm{G} / 1 \\
\text { If the bleeding is controlled: } \\
\text { - Evaluation of prophylactic anticoagulation } \\
\text { - Interruption/cessation of anticoagulation, depending on } \\
\text { the bleeding complication and the indication for } \\
\text { anticoagulation }\end{array}$ \\
\hline
\end{tabular}

$\mathrm{PT}=$ Prothrombin time; $\mathrm{aPTT}=$ activated partial prothromboplastin time; $\mathrm{INR}=$ internalized normalized ratio; i.v. $=$ intravenous; $\mathrm{PCC}$ = prothrombin complex concentrates; aPCC = activated prothrombin complex concentrates; rFVIIa = recombinant factor VIIa.

only then other coagulation problems of the patient can be clearly diagnosed.

For FXa inhibitors the reversal agent andexanet alfa may soon be available (approved May 2018 in the US). Should a direct reversal agent not be available, the Swiss Society for Anesthesiology and Reanimation recommends the administration of tranexamic acid and potentially desmopressin to attempt a normalization of hemostasis, before using concentrates with pro-coagulant factors such as prothrombin complex concentrate (PCC) in severe bleeding $[31,64]$. Activated PCC should only be considered in a patient with life-threatening, intractable bleeding $[29,63]$.
Once the bleeding has been stopped, thromboembolic prophylaxis needs to be restarted in all patients as soon as possible, as patients under oral anticoagulation are particularly prone to thrombosis and thromboembolic complications (table 10).

\section{Outlook}

Currently under investigation are two more reversal agents, andexanet alfa (targeting all FXas) and PER977 (or aripazine or ciraparantag, targeting FXa inhibitors, dabigatran and heparins) [61]. 


\section{Disclosure Statement}

DRS: Dr. Spahn's academic department is receiving grant support from the Swiss National Science Foundation, Berne, Switzerland, the Ministry of Health (Gesundheitsdirektion) of the Canton of Zurich, Switzerland, for Highly Specialized Medicine, the Swiss Society of Anesthesiology and Reanimation (SGAR), Berne, Switzerland, the Swiss Foundation for Anesthesia Research, Zurich, Switzerland, CSL Behring, Berne, Switzerland, Vifor SA, Villarssur-Glâne, Switzerland. Dr. Spahn is co-chair of the ABC-Trauma Faculty, sponsored by unrestricted educational grants from Novo Nordisk Health Care AG, Zurich, Switzerland, CSL Behring $\mathrm{GmbH}$, Marburg, Germany, LFB Biomédicaments, Courtaboeuf Cedex, France and Octapharma AG, Lachen, Switzerland. Dr. Spahn has received honoraria or travel support for consulting or lecturing from: Danube University of Krems, Austria, US Department of Defense, Washington, USA, European Society of Anesthesiology, Brussels, BE, Korea, Korean Society for Patient Blood Management, Seoul, Korea, Korean Society of Anesthesiologists, Seoul, Baxter AG, Volketswil, Switzerland, Baxter S.p.A., Roma, Italy, Bayer AG, Zürich, Switzerland, Bayer Pharma AG, Berlin, Germany, B. Braun Melsungen AG, Melsungen, Germany, Boehringer Ingelheim $\mathrm{GmbH}$, Basel, Switzerland, Bristol-MyersSquibb, Rueil-Malmaison Cedex, France and Baar, Switzerland, CSL Behring GmbH, Hattersheim am Main, Germany and Berne, Switzerland, Celgene International II Sàrl, Couvet, Switzerland, Curacyte AG, Munich, Germany, Daiichi Sankyo AG, Thalwil, Switzerland, GlaxoSmithKline GmbH \& Co. KG, Hamburg, Germany, Haemonetics, Braintree, MA, USA, Instrumentation Laboratory (Werfen), Bedford, MA, USA, LFB Biomédicaments, Courtaboeuf Cedex, France, Merck Sharp \& Dohme, Kenilworth, NJ, USA, Octapharma AG, Lachen, Switzerland, Organon AG, Pfäf-
fikon/SZ, Switzerland, PAION Deutschland GmbH, Aachen, Germany, Pharmacosmos A/S, Holbaek, Denmark, Photonics Healthcare B.V., Utrecht, Netherlands, Roche Diagnostics International Ltd, Reinach, Switzerland, Roche Pharma AG, Reinach, Switzerland, Sarstedt AG \& Co., Sevelen, Switzerland and Nümbrecht, Germany, Schering-Plough International, Inc., Kenilworth, NJ, USA, Tem International GmbH, Munich, Germany, Verum Diagnostica GmbH, Munich, Germany, Vifor Pharma, Munich, Germany, Vienna, Austria and Villars-sur-Glâne, Switzerland, Vifor (International) AG, St. Gallen.

JHB: Grant support from SNF and Swiss Heart Foundation, grant support, travel support, honoraria for consulting or lecturing from Bayer, Boehringer Ingelheim, Bristol-Myers-Squibb, Daiichi Sankyo, Pfizer, Astra Zeneca.

AB: travel support, honoraria for consulting or lecturing from Bayer, Boehringer Ingelheim, Bristol-Myers-Squibb, Daiichi Sankyo, Pfizer

PGC: travel support, honoraria for consulting or lecturing from Bayer, Boehringer Ingelheim, Bristol-Myers-Squibb, Daiichi Sankyo.

CK: travel support, honoraria for consulting or lecturing from Bayer, Boehringer Ingelheim, Bristol-Myers-Squibb, Daiichi Sankyo.

FM: travel support, honoraria for consulting or lecturing from Bayer, Boehringer Ingelheim, Bristol-Myers-Squibb, Daiichi Sankyo.

$\mathrm{KN}$ : travel support, honoraria for consulting or lecturing from Bayer, Boehringer Ingelheim, Bristol-Myers-Squibb, Daiichi Sankyo.

WK: travel support, honoraria for consulting or lecturing from Bayer, Boehringer Ingelheim, Bristol-Myers-Squibb, Daiichi Sankyo.

\section{References}

- 1 Patti G, Di Gioia G, Cavallari I, Nenna A: Safety and efficacy of nonvitamin K antagonist oral anticoagulants versus warfarin in diabetic patients with atrial fibrillation: a studylevel meta-analysis of phase III randomized trials. Diabetes Metab Res Rev 2017;33:e2876.

-2 Dentali F, Riva N, Crowther M, Turpie AGG, Lip GYH, Ageno W: Efficacy and safety of the novel oral anticoagulants. a systematic review and meta-analysis of the literature. Circulation 2012;126:2381-2391.

-3 Hicks T, Stewart F, Eisinga A: NOACs versus warfarin for stroke prevention in patients with AF: a systematic review and meta-analysis. Open Heart 2016;3:e000279.

4 Xiong Q, Lau YC, Senoo K, Lane DA, Hong K, Lip GYH: Non-vitamin K antagonist oral anticoagulants (NOACs) in patients with concomitant atrial fibrillation and heart failure: a systemic review and meta-analysis of randomized trials. Eur J Heart Fail 2015;17: 1192-1200

5 Vanassche T, Hirsh J, Eikelboom JW, Ginsberg JS: Organ-specific bleeding patterns of anticoagulant therapy: lessons from clinical trials. Thromb Haemost 2014;112:918-923.

6 Swissmedicinfo: Xarelto. Available from: www.swissmedicinfo.ch/.

7 Swissmedicinfo: Eliquis. Available from: www.swissmedicinfo.ch/.

8 Swissmedicinfo: Lixiana. Available from: www.swissmedicinfo.ch/.
9 Swissmedicinfo: Pradaxa. Available from: www.swissmedicinfo.ch/.

10 Wigle P, Hein B, Tubb M: Updated guidelines on outpatient anticoagulation. Am Fam Physician 2013;87:556-566

11 Sunkara T, Ofori E, Zarubin V, Caughey ME, Gaduputi V, Reddy M: Perioperative management of direct oral anticoagulants (DOACs): a systemic review supplementary issue: perioperative medicine. Heal Serv Insights 2016;9:25-36.

12 Büller HR, Prins MH, Lensing AWA, Decousus $\mathrm{H}$, Jacobson BF, Minar E, et al: Oral Rivaroxaban for the Treatment of Symptomatic Pulmonary Embolism. N Engl J Med 2012; 366:1287-1297.

13 Janssen Pharmaceuticals Inc: Highlights of Prescribing Information Xarelto ${ }^{\circledR}$ for FDA. 2018, pp 1-19.

14 Boehringer-Ingelheim: Highlights of Prescribing Information Pradaxa ${ }^{\circledR}$ for FDA. 2018. https://docs.boehringer-ingelheim.com/ Prescribing\%20Information/PIs/Pradaxa/ Pradaxa.pdf (last accessed October 17, 2018).

15 Bristol-Myers Squibb Company, Pfizer Inc: Highlights of Prescribing Information Eliquis ${ }^{\circledR}$ for FDA. 2017, pp 1-64.

16 Bayer Pharma AG: Summary of Product Characteristics Xarelto ${ }^{\circledR}$ for EMA 2018, pp $1-222$
17 Bristol-Myers Squibb, Pfizer EEIG: Summary of Product Characteristics Eliquis ${ }^{\circledR}$ for EMA. 2017, pp 1-82.

18 Boehringer-Ingelheim: Summary of Product Characteristics Pradaxa ${ }^{\circledR}$ for EMA 2017, pp 1-166.

19 Klauser W, Dütsch M: Practical management of new oral anticoagulants after total hip or total knee arthroplasty. Musculoskelet Surg 2013;97:189-197.

20 Sié P, Samama CM, Godier A, Rosencher N, Steib A, Llau JV, et al: Surgery and invasive procedures in patients on long-term treatment with direct oral anticoagulants: thrombin or factor-Xa inhibitors. Recommendations of the Working Group on Perioperative Haemostasis and the French Study Group on Thrombosis and Hemostasis. Arch Cardiovasc Dis 2011;104:669-676.

21 Schwarb H, Tsakiris DA: New Direct oral anticoagulants (DOAC) and their use today. Dent J 2016;4:1-11.

22 Merki R, Schwarb H, Tsakiris DA: Direkte orale Antikoagulantien. Monitoring wann und wie? Ther Umschau 2016;73:613-617.

23 Van Gorp RH, Schurgers LJ: New insights into the pros and cons of the clinical use of vitamin $\mathrm{K}$ antagonists (VKAs) versus direct oral anticoagulants (DOACs). Nutrients 2015;7:9538-9557. 
24 Graf L, Korte W: Direkte orale Antikoagulantien und Medikamenteninteraktionen. Ther Umschau 2015;72:99-104.

-25 Kubitza D, Becka M, Roth A, Mueck W: The influence of age and gender on the pharmacokinetics and pharmacodynamics of rivaroxaban-an oral, direct factor Xa inhibitor. J Clin Pharmacol 2013;53:249-255.

26 Walenga JM, Adiguzel C: Drug and dietary interactions of the new and emerging oral anticoagulants. Int J Clin Pract 2010;64:956967

-27 Wessler JD, Grip LT, Mendell J, Giugliano RP: The P-glycoprotein transport system and cardiovascular drugs. J Am Coll Cardiol 2013; 61:2495-2502.

28 Chang S-H, Chou I-J, Yeh Y-H, Chiou M-J, Wen M-S, Kuo C-T, et al: Association between use of non-vitamin $\mathrm{K}$ oral anticoagulants with and without concurrent medications and risk of major bleeding in nonvalvular atrial fibrillation. JAMA 2017;318: 1250-1259.

29 Steffel J, Verhamme P, Potpara TS, Albaladejo P, Antz M, Desteghe L, et al: The $2018 \mathrm{Eu}$ ropean Heart Rhythm Association Practical Guide on the use of non-vitamin K antagonist oral anticoagulants in patients with atrial fibrillation. Eur Heart J 2018;39:1330-1393.

30 Nagler M, Erne P, Babst R, Korte W, Wuillemin WA: Periinterventionelles Management der Antikoagulation und Antiaggregation. Swiss Med Forum 2011;11:407-412.

>31 Graf L, Korte W: Perioperatives Management der Antikoagulantien. Ther Umschau 2016; 73:545-549.

-32 Baglin T, Keeling D, Kitchen S: Effects on routine coagulation screens and assessment of anticoagulant intensity in patients taking oral dabigatran or rivaroxaban: Guidance from the British committee for Standards in Haematology. Br J Haematol 2012;159:427-429.

-33 Favaloro EJ, Lippi G: Laboratory testing in the era of direct or non-vitamin $\mathrm{K}$ antagonist oral anticoagulants : a practical guide to measuring their activity and avoiding diagnostic errors. Semin Thromb Hemost 2015;41:208-227.

-34 Lippi G, Favaloro EJ: Recent guidelines and recommendations for laboratory assessment of the direct oral anticoagulants (DOACs): Is there consensus? Clin Chem Lab Med 2015; 53:185-197.

-35 Salmonson T, Dogné J-M, Janssen H, Burgos JG, Blake P: Non-vitamin-K oral anticoagulants and laboratory testing: now and in the future. Eur Heart J Cardiovasc Pharmacother 2017;3:42-47

-36 Hillarp A, Baghaei F, Fagerberg Blixter I, Gustafsson KM, Stigendal L, Sten-Linder M, et al: Effects of the oral, direct factor Xa inhibitor rivaroxaban on commonly used coagulation assays. J Thromb Haemost 2011;9:133-139.

-37 Samuelson BT, Cuker A, Siegal DM, Crowther M, Garcia DA: Laboratory assessment of the anticoagulant activity of direct oral anticoagulants. Chest 2017;151:127-138.

- 38 Douxfils J, Mullier F, Loosen C, Chatelain C, Chatelain B, Dogné JM: Assessment of the impact of rivaroxaban on coagulation assays Laboratory recommendations for the monitoring of rivaroxaban and review of the literature. Thromb Res 2012;130:956-966.
39 Douxfils J, Mullier F, Robert S, Chatelain C, Chatelain B, Dogné JM: Impact of dabigatran on a large panel of routine or specific coagulation assays: laboratory recommendations for monitoring of dabigatran etexilate. Thromb Haemost 2012;107:985-997.

40 Gosselin RC, Adcock DM: Assessing nonvitamin $\mathrm{K}$ antagonist oral anticoagulants (NOACs ) in the laboratory. Int J Lab Hematol 2015;37:46-51.

41 Tran H, Joseph J, Young L, McRae S, Curnow J, Nandurkar $\mathrm{H}$, et al: New oral anticoagulants: a practical guide on prescription, laboratory testing and peri-procedural/bleeding management. Intern Med J 2014;44:525-536.

42 Hovaguimian F, Köppel S, Spahn DR: Safety of anticoagulation interruption in patients undergoing surgery or invasive procedures : a systematic review and meta- analyses of randomized controlled trials and non-randomized studies. World J Surg 2017;41:24442456.

43 Godier A, Dincq A, Radu A, Leblanc I, Antona $\mathrm{M}$, Vasse $\mathrm{M}$, et al: Predictors of pre-procedural concentrations of direct oral anticoagulants: a prospective multicentre study. Eur Heart J 2017;38:2431-2439.

44 Beyer-Westendorf J, Gelbricht V, Förster K, Ebertz F, Köhler C, Werth S, et al: Peri-interventional management of novel oral anticoagulants in daily care: results from the prospective Dresden NOAC registry. Eur Heart J 2014;35:1888-1896.

45 Douketis JD, Spyropoulos AC, Kaatz S, Becker RC, Caprini JA, Dunn AS, et al: Perioperative bridging anticoagulation in patients with atrial fibrillation. N Engl J Med 2015;373:823-833.

46 Raval AN, Cigarroa JE, Chung MK, Diaz-Sandoval LJ, Diercks D, Piccini JP, et al: Management of patients on non-vitamin $\mathrm{K}$ antagonist oral anticoagulants in the acute care and periprocedural setting: a scientific statement from the American Heart Association. Circulation 2017;135:e604-e633.

47 Spyropoulos AC, Al-Badri A, Sherwood MW, Douketis JD: Periprocedural management of patients receiving a vitamin $\mathrm{K}$ antagonist or a direct oral anticoagulant requiring an elective procedure or surgery. J Thromb Haemost 2016;14:875-885.

48 Gallego P, Apostolakis S, Lip GYH: Bridging evidence-based practice and practice-based evidence in periprocedural anticoagulation. Circulation 2012;126:1573-1576.

49 Kaserer A, Schedler A, Jetter A, Seifert B, Spahn DR, Stein P, Studt JD: Risk factors for higher-than-expected residual rivaroxaban plasma concentrations in real-life patients. Thromb Haemost 2018;118:808-817.

50 Douketis JD, Spyropoulos AC, Anderson JM, Arnold DM, Bates SM, Blostein M, et al: The Perioperative Anticoagulant Use for Surgery Evaluation (PAUSE) Study for patients on a direct oral anticoagulant who need an elective surgery or procedure: design and rationale. J Thromb Haemost 2017;117:2415-2424.

51 Arbeitsgruppe Lipide und Atherosklerose der Schweizerischen Gesellschaft: Antithrombotika 2017. www.agla.ch/blog/2018/09/aglabringt-digitale-version-des-pocketguides-antithrombotika-2017-zum-download (last accessed October 17, 2018).
52 Levy JH, Ageno W, Chan NC, Crowther M, Verhamme P, Weitz JI: When and how to use antidotes for the reversal of direct oral anticoagulants: guidance from the SSC of the ISTH. J Thromb Haemost 2015;14:623-627.

53 Pernod G, Albaladejo P, Godier A, Samama CM, Susen S, Gruel Y, et al: Management of major bleeding complications and emergency surgery in patients on long-term treatment with direct oral anticoagulants, thrombin or factor-Xa inhibitors : Proposals of the Working Group on Perioperative Haemostasis (GIHP) - March 2013. Arch Cardiovasc Dis 2013;106:382-393.

54 Ruff CT, Giugliano RP, Antman EM: Management of bleeding with non-vitamin $\mathrm{K}$ antagonist oral anticoagulants in the era of specific reversal agents. Circulation 2016;134: 248-261.

55 Albaladejo P, Bonhomme F, Blais N, Collet J-P, Faraoni D, Fontana P, et al: Management of direct oral anticoagulants in patients undergoing elective surgeries and invasive procedures: updated guidelines from the French Working Group on Perioperative Hemostasis (GIHP) - September 2015. Anaesth Crit Care Pain Med 2017;36:73-76.

56 Goodman BS, House LM, Vallabhaneni S, Mallempati S, Willey MR, Smith MT: Anticoagulant and antiplatelet management for spinal procedures: a prospective, descriptive study and interpretation of guidelines. Pain Med 2017;18:1218-1224.

57 Arora H: New anticoagulants and emerging trends in regional anesthesia. Anesthesiol News 2015;October 20:26-31.

58 Rosencher N, Bonnet MP, Sessler DI: Selected new antithrombotic agents and neuraxial anaesthesia for major orthopaedic surgery: management strategies. Anaesthesia 2007;62: 1154-1160.

59 Spyropoulos AC, Douketis JD: How I treat anticoagulated patients undergoing an elective procedure or surgery. Blood 2012;120: 2954-2962.

60 Wang X, Mondal S, Wang J, Tirucherai G, Zhang D, Boyd RA, et al: Effect of activated charcoal on apixaban pharmacokinetics in healthy subjects. Am J Cardiovasc Drugs 2014;14:147-154

61 Dalal J, Bhave A, Chaudhry G, Rana P: Reversal agents for NOACs: connecting the dots. Indian Heart J 2016;68:559-563.

62 Beyer-Westendorf J, Förster K, Pannach S Ebertz F, Gelbricht V, Thieme C, et al: Rates, management and outcome of bleeding complications during rivaroxaban therapy in daily care: results from the Dresden NOAC registry. Blood 2014;124:955-962.

63 Weitz JI, Pollack CVJ: Practical management of bleeding in patients receiving non-vitamin $\mathrm{K}$ antagonist oral anticoagulants. Thromb Haemost 2015;114:1113-1126.

64 SGAR/SSAR: Empfehlung bei massiver Blutung, 2017;1-5. www.sgar-ssar.ch/fileadmin/ user_upload/sgar-ssar/public/Services/Downloads/perioperatives_Gerinnungs/Standard Algorithmus_22032017.pdf(last accessed November 14, 2018).

65 Lucas S, Wuillemin WA: Praktische Tipps und Tricks zu den DOAC. Ther Umschau 2016;73:561-566. 